\title{
Forlap Scraper Menggunakan Aplikasi Android
}

\author{
Sigit Rizqi Ramadan, Bana Handaga \\ Program Studi Informatika \\ Univesrsitas Muhammadiyah Surakarta \\ Surakarta, Indonesia \\ rizqiramadan2242@gmail.com,bana.handaga@gmail.com
}

\begin{abstract}
Abstraksi - Android merupakan salah satu platform sistem operasi besutan dari Google yang diterapkan pada perangkat mobile berbasis Linux seperti smartphone dan komputer tablet. Tingkat penggunaan android di masyarakat semakin meningkat seiring perkembangannya yang mampu membantu masyarakat dalam pekerjaan sehari-hari khususnya dalam kegiatan berkomunikasi dan saling menukar informasi. Kecepatan dalam mendapat dan mengirim informasi menjadi alasan dalam pengembangan teknologi saat ini, seperti halnya dengan kebutuhan mahasiswa dalam mengakses Forum Laporan Pendidikan Tingi atau Forlap Dikti. Forlap Dikti merupakan suatu laman website yang dikembangkan oleh Kementrian Riset, Teknologi dan Pendidikan Tinggi yang berisi data aktivitas akademik mahasiswa seluruh Indonesia yang didasarkan pada data pelaporan perguruan tinggi yang ada di Indonesia. Oleh karena itu dibutuhkan aplikasi pendukung yang mampu untuk memudahkan dan mempercepat kebutuhan mengakses informasi pada laman website Forlap Dikti dengan menggunakan aplikasi android. Penelitian ini bertujuan untuk membuat suatu aplikasi mobile sistem informasi berbasis android yang mampu mempermudah dan mempercepat mahasiswa Universitas Muhammadiyah Surakarta untuk dalam mengakses data mahasiswa pada laman website Forlap RistekDikti menggunakan metode web scraping menggunakan python, Android Studio dalam bahasa pemrograman java sebagai software IDE dan REST API untuk pertukaran data. Berdasarkan pengujian yang dilakukan kepada 30 mahasiswa Universitas Muhammadiyah Surakarta dapat diketahui bahwa $90 \%$ responden setuju aplikasi ini layak digunakan.
\end{abstract}

Katakunci - Android; Forlap Dikti; REST API; Web Scraper

\footnotetext{
Abstracts - Android is one of the operating system platforms created by Google that is applied to Linux-based mobile devices such as smartphones and tablet computers. The level of android usage in the community increases with its development which is able to help the community in their daily work in communicating and exchanging information. The speed of receiving and sending information is the reason for the development of current technology, such as facilitating the needs of students in accessing the Higher Education Report Forum or Forlap Dikti. Forlap Dikti is a site page developed by the Ministry of Research, Technology and Higher Education which contains academic data for students throughout Indonesia that contain data about universities in Indonesia. Therefore a supporting application is needed that is able to facilitate and increase information needs on the Forlap Dikti website using the android application. This study was designed to
}

create an Android-based information system mobile application that is able to facilitate and enhance Muhammadiyah Surakarta University students to access student data on the Forlap Dikti web page using the web erosion method using python, Android Studio in java using the IDE and REST API software to transfer data. Based on tests conducted on 30 Muhammadiyah University of Surakarta students, it can be seen that $90 \%$ of respondents agreed that the application was feasible.

Keywords - Android; Forlap Dikti; REST API; Web Scraper

\section{PENDahuluan}

Forum Laporan Pendidikan Tinggi atau yang disebut Forlap Dikti merupakan sebuah pangkalan data dari Kementrian Riset, Teknologi dan Pendidikan Tinggi untuk memberi informasi atau data tentang perguruan tinggi, mahasiswa maupun dosen. Forlap Dikti seringkali digunakan sebagai sarana untuk memeriksa data aktivitas akademik mahasiswa, riwayat dosen pengajar dan profil perguruan tinggi yang ada di Indonesia. Forlap menjadi sebuah hal yang sangat penting bagi kelangsungan perguruan tinggi, khususnya mahasiswa yang ingin mengajukan penilitian, beasiswa, perlombaan maupun fresh graduate karena semua data mahasiswa tersebut akan dijadikan acuan legalitas dari data mahasiswa dan ijazah.

Ijazah adalah dokumen pengakuan prestasi belajar dan/atau penyelesaian suatu jenjang pendidikan tinggi sesudah lulus ujian yang diselenggarakan perguruan tinggi (Peraturan Mendikbud Nomor 81 Tahun 2014). Ijazah merupakan suatu bentuk pengakuan dari badan yang legal dan bukti kompetensi siswa yang sangat dibutuhkan untuk melamar pekerjaan, biasanya perusahaan akan meminta para pelamar untuk melampirkan ijazah mereka yang sudah dilegalisir sebagai bukti bahwa telah benar-benar menyelesaikan jenjang pendidikan.

Forlap Dikti menyimpan data mahasiswa dari sebuah instansi pendidikan tinggi dari awal masuk sampai keluarnya nomor seri Penomoran Ijazah Nasional sesuai dengan Surat Edaran Jenderal Pembelajaran dan Kemahasiswaan Nomor 700/SE/2017 tentang penggunaan Penomoran Ijazah Nasional (PIN) dan Sistem Verivikasi Ijazah secara Elektronik (SIVIL) yang dikemudian hari akan sangat dibutuhkan bagi mahasiswa 
maupun instansi lainnya. Forlap Dikti dapat dilihat oleh semua komponen masyarakat dengan mengakses laman https://forlap.ristekdikti.go.id menggunakan web browser, namun seiring perkembangan teknologi yang sangat pesat maka perlu diterapkannya suatu terobosan baru untuk mengirim maupun menerima informasi dengan lebih cepat dan efisien.

Penggunaan media informasi berbasis website kini mulai beralih menjadi berbasis mobile, hal tersebut dikarenakan kemampuan teknologi mobile yang semakin menandingi kualitas komputasi komputer desktop. Salah satu platform mobile yang berkembang saat ini adalah android. Android merupakan suatu sistem operasi berbasis kernel Linux dan dikembangkan oleh Google yang dirancang untuk perangkat seluler layar sentuh seperti smartphone maupun tablet (Mukherjee dkk, 2015).

Saat ini perkembangan teknologi sudah merambah sampai ke segala aspek kehidupan masyarakat yang dimanfaatkan untuk mempermudah mereka dalam melakukan aktivitas sehari-hari. Salah satunya adalah komunikasi, dengan adanya teknologi mobile masyarakat dimudahkan dalam melakukan komunikasi antara jarak dan waktu baik secara verbal, non verbal maupun visual.

Pemanfaatan teknologi mobile sebagai sistem informasi dengan sistem operasi android merupakan pembaruan teknologi informasi yang tepat untuk memenuhi kebutuhuan informasi dalam institusi (Amrullah, H., \& Handaga, B., 2017). Teknologi mobile tidak lagi hanya menjadi alat komunikasi, namun juga menjadi bagian penting dari kehidupan sehari-hari masyarakat . Seperti halnya dengan smartphone yang semakin popular, kemampuan seperti mendengarkan musik, menonton video, tweeting, dan beberapa lainnya dapat dipindahkan dari komputer kedalam smartphone (Ma, L. dkk., 2014).

Salah satu teknik pencarian informasi yang diadopsi oleh beberapa search engine untuk mengekstrak informasi pada website melalui bot yaitu web scraper. Web scraper adalah proses menganalisa dan mengambil data tertentu dari sebuah halaman website dalam bahasa markup seperti HTML atau $X H T M L$ secara semi-terstruktur untuk digunakan bagi kepentingan lain (Josi, dkk. 2014). Web scraper dapat melakukan transformasi data yang tidak terstruktur pada website dalam format HTML menjadi data terstruktur yang dapat disimpan dan dianalisa dalam database.

API adalah sebuah isyarat format pesan yang digunakan untuk berkomunikasi dari program aplikasi ke sistem lainnya. API kini telah dikembangkan menjadi sebuah arsitektur client/server web yang mampu melakukan request dan response untuk mentransfer resources atau data, pengembangan tersebut dikenal sebagai REST API dan menggunakan format data JSON (JavaScript Object Nation). Resources yang dimaksud dalam REST API adalah setiap link URL (Richardson, L., \& Ruby, S. 2007).
Berdasarkan latar belakang diatas, penulis bermaksud untuk membuat penelitian, merancang dan mengimplementasikan sebuah aplikasi web scraper berbasis android. Aplikasi ini akan mengumpulkan data mahasiswa Univesitas Muhammadiyah Surakarta dari laman Forlap Dikti yang disimpan dalam sebuah database pada web server, kemudian android sebagai client melakukan request melalui REST API untuk menampilkan data mahasiswa di layar smartphone android. Dengan adanya aplikasi ini, pengembang berharap dapat membantu mempermudah para mahasiswa maupun instansi yang ingin atau membutuhkan data aktivitas akademik mahasiswa Universitas Muhammadiyah Surakarta..

\section{METODE}

Forlap UMS merupakan sebuah aplikasi sistem informasi berbasis android yang digunakan untuk mengekstrak data mahasiswa Universitas Muhammadiyah Surakarta (UMS) dari halaman website dari Forum Laporan Kementrian Riset Teknologi dan Pendidikan Tinggi (Forlap Kemenristekdikti) yaitu https://forlap.ristekdikti.go.id kedalam sebuah tampilan pada smartphone android yang menyajikan data sesuai dengan data yang ada pada website tersebut. Aplikasi ini menawarkan sebuah terobosan baru dalam kemudahan pencarian data pada database menggunakan media yang seringkali digunakan oleh masyarakat pada umumnya dan mahasiswa pada khususnya yaitu smartphone android dimana user hanya perlu memasukkan Nomor Induk Mahasiswa (NIM) dan Program Studi saja. Berikut adalah use case diagram user untuk aplikasi Forlap UMS dalam gambar 1 .

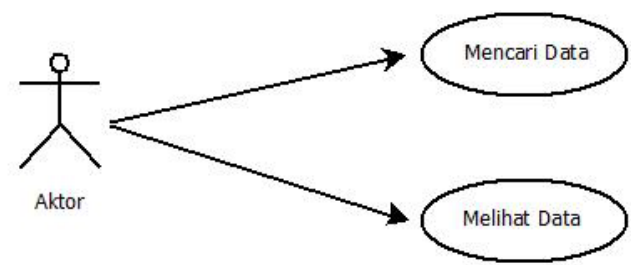

Gambar 1. Use case diagram

Aplikasi ini dibangun dengan melewati beberapa tahapan penelitian meliputi analisis kebutuhan, pengumpulan data, perancangan aplikasi, implementasi dan pengujian. Hal tersebut dilakukan demi terwujudnya hasil penelitian yang baik dan selaras dengan tujuan pengembang. Pada tahap analisis kebutuhan, pengembang memerlukan beberapa alat pendukung baik hardware maupun software. Hardware yang diperlukan meliputi Laptop Asus A455LD Intel ${ }^{\circledR}$ Core $^{\mathrm{TM}}$ i3 CPU@1.90GHz, RAM 4GB, dan smartphone dengan android version 8.1.0 (Oreo) Snapdragon 625. Lalu untuk software yang diperlukan meliputi Sublime Text 3, XAMPP v.3.2.2, dan Android Studio 3.2. Konsep alur kerja aplikasi Forlap UMS secara umum dapat dilihat pada Gambar 2. 


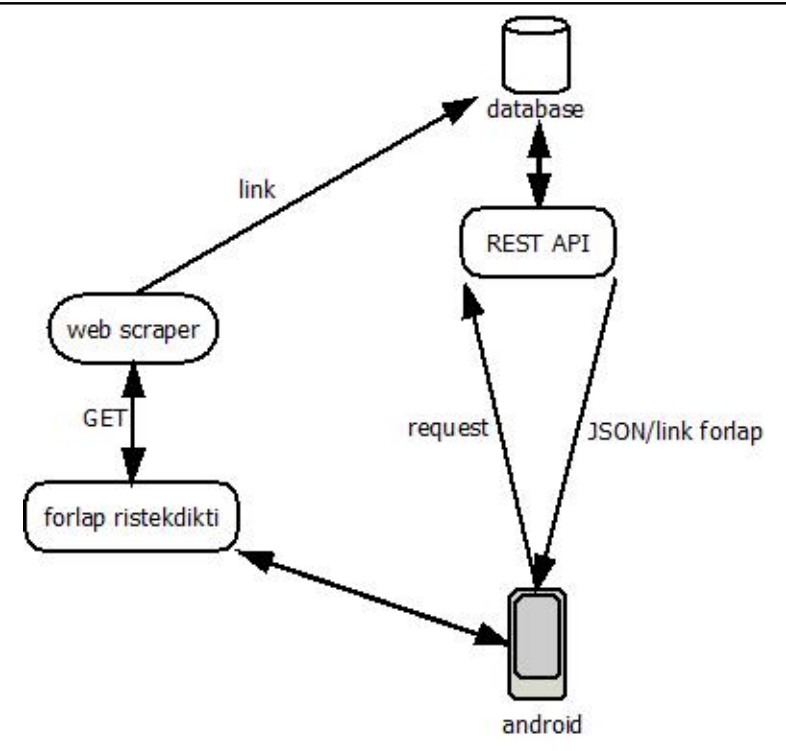

Gambar 2. Konsep alur kerja aplikasi Forlap UMS

Aplikasi ini menggunakan bahasa pemrograman python yang menggunakan BeautifulSoup4 sebagai library untuk melakukan web scraping atau ekstraksi pada halaman website, kemudian bahasa pemrograman PHP dengan Framework Laravel yang digunakan untuk membuat REST API, lalu untuk database menggunakan $M y S Q L$ untuk menyimpan data hasil scraping, pengembang juga menggunakan bahasa pemrograman java untuk membuat program android pada smartphone dan menggunakan retrofit 2 sebagai library untuk melakukan post request dari android ke web server. Sedangkan untuk tampilan pada layar smartphone android menggunakan web view. Activity diagram pada Forlap UMS dapat dilihat pada Gambar 3.

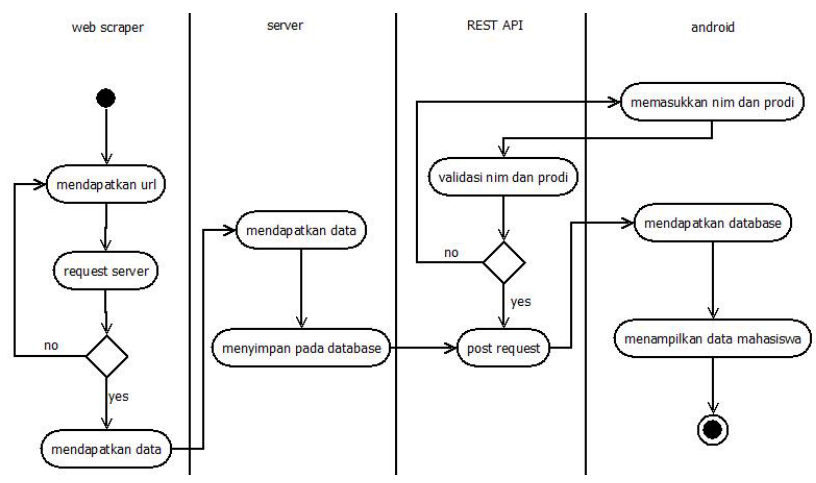

Gambar 3. Diagram activity aplikasi Forlap UMS

Tahapan pengumpulan data dimulai dengan melakukan ekstrasi pada halaman website Forlap Dikti https://forlap.ristekdikti.go.id menggunakan basis bahasa pemrograman python, python digunakan karena dianggap relatif lebih mudah dan simpel dalam pengoperasiannya untuk membuat proram yang berguna untuk melakukan ekstraksi atau web scraping. Proses ekstraksi tersebut dibantu dengan menggunakan BeautifulSoup4, BeautifulSoup4 merupakan sebuah library khusus yang disediakan oleh python digunakan untuk memisah dan menyaring data yang diperlukan dari file HTML maupun XML (Ambre dkk, 2019). Data yang diekstrak dari halaman website tersebut adalah Nomor Induk Mahasiswa dan link dari Nomor Induk Mahasiswa Universitas Muhammadiyah Surakarta secara keseluruhan. Link tersebut akan menuju halaman website Forlap Dikti yang berisi tentang data dari mahasiswa terkait.

Proses ekstraksi dimulai dengan melakukan request kepada server dari website Forlap Dikti, apabila server memberi response maka sistem akan memeriksa stuktur data dari laman web, hal tersebut dilakukan untuk mengetahui langkah dan proses ekstraksi data yang akan dilakukan sehingga didapatkan algoritma ekstraksi data dimulai dari melihat tabel seluruh program studi yang ada pada Universitas Muhammadiyah Surakarta, kemudian dari tabel tersebut akan diurai sehingga bisa diambil data nama program studi, status program studi, jenjang pendidikan, jumlah mahasiswa dan link profil program studi.

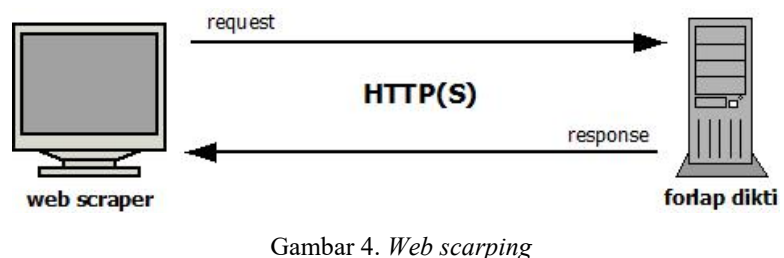

Data tersebut selanjutnya dibuat tabel sesuai dengan nama program studi dan jenjang pendidikan yang didapat, lalu sistem membaca link profil program studi yang telah diesktraksi dari tabel program studi, link profil program studi tersebut menuju ke halaman profil program studi yang berisi tabel umum, dosen dan mahasiswa. Dari sini sistem hanya melakukan ekstraksi pada tabel mahasiswa, tabel mahasiswa tersebut berisi tahun semester dan jumlah mahasiswa yang terdaftar pada semester tahun itu.

Kemudian sistem akan membaca link data mahasiswa dari isi tabel tersebut dan menuju halaman data mahasiswa, dari halaman tersebut akan terlihat seluruh nama mahasiswa yang terdaftar pada semester itu, setiap halaman hanya menyediakan tabel yang berisi 20 baris nama mahasiswa, maka dari itu sistem harus melakukan looping pada setiap halaman tabel data mahasiswa supaya dapat mengekstrak data setiap mahasiswa. Data mahasiswa yang diesktrak berupa nomor induk mahasiswa, link mahasiswa dan nama mahasiswa, kemudian sistem melakukan looping dari proses ekstraksi pada keseluruhan daftar program studi, profil program studi dan data mahasiswa yang ada pada Universitas Muhammadiyah Surakarta. 
Data yang telah dikumpulkan selanjutnya disimpan dalam sebuah database menggunakan XAMPP local server dengan dua tabel yaitu tabel nim dan tabel prodi, kemudian di-export menjadi file berekstensi .sql untuk kemudian di-upload ke dalam web server. Web server yang digunakan adalah $M y S Q L$, MySQL merupakan sebuah database management system yang dikembangkan oleh Oracle Corporation. MySQL bersifat open souce yang memungkinkan setiap orang untuk menggunakan dan mengembangkannya sesuai dengan kebutuhan. MySQL dapat dijalankan pada komputer desktop, laptop, aplikasi maupun server web. Selain itu MySQL database server juga dinilai sangat cepat, dapat diandalkan dan mudah dikelola.

Selanjutnya dalam web server tersebut juga di-upload file REST API dengan memanfaatkan fitur backend API pada Laravel. REST API merupakan serangkaian fungsi yang digunakan untuk meminta dan menerima tanggapan melalui protocol HTTP seperti GET dan POST. REST API sangat memungkinkan digunakan diberbagai bahasa pemrograman sehingga dapat membantu dalam pertukaran data dari client dan server. Skema post request REST API dapat dilihat pada gambar 5 .

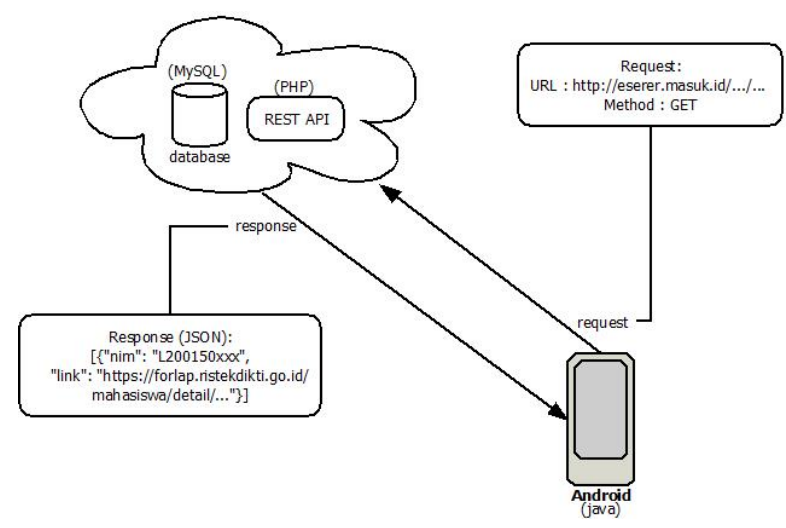

Gambar 5. Post request REST API

Berdasarkan skema diatas, pengembang menggunakan library retrofit. Retrofit merupakan suatu client HTTP typesafe untuk android dan java yang difungsikan sebagai sarana penghubung kelayanan web REST dengan menerjemahkan API ke interface java. Retrofit juga membantu penggunaan data JSON atau XML untuk kemudian diurai menjadi Plain Old Java Objects (POJOs) sehingga aplikasi ini dapat melakukan operasi POST request pada API di web server.

Kemudian android sebagai client melakukan request pada web server melalui REST API dengan input Nomor Induk Mahasiswa Universitas Muhammadiyah Surakarta dan Program Studi mahasiswa. Web server akan memberikan balasan berupa JSON code (Java Script Object Notation) yang berisi link mahasiswa dari Nomor Induk Mahasiswa dan Program Studi yang telah dimasukkan, kode tersebut kemudian diterjemahkan oleh android dan menampilkan halaman website Forlap Dikti melalui web view.

\section{HASIL DAN PEMBAHASAN}

Pencapaian dari penelitian yang telah dilakukan oleh pengembang adalah mengasilkan sebuah aplikasi sistem informasi berbasis aplikasi android. Sistem ini dirancang untuk memudahkan user dalam mengakses data mahasiswa sesuai data laporan yang tertera pada halaman webite Forlap Dikti serta menawarkan suatu metode untuk melakukan pencarian data secara relatif lebih mudah dibanding mengakses pada halaman website melalui browser. Aplikasi ini dibangun dengan basis web scraping, berikut beberapa kode pengambilan data website target dalam bahasa pemrograman python:

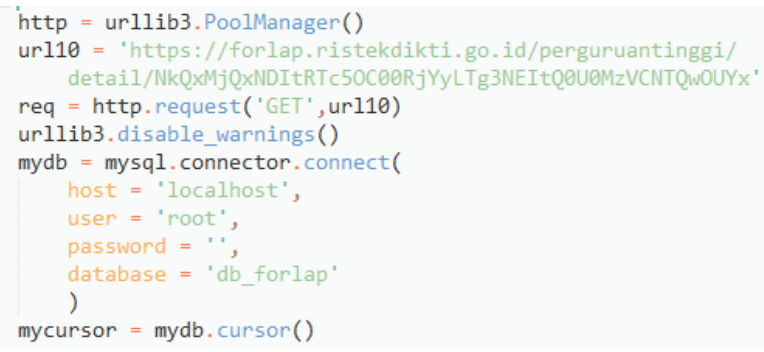

Gambar 6. Kode untuk melakukan request ke server

Berdasarkan gambar 6, varibel url10 pada baris 7 dengan tipe data string digunakan untuk menyimpan link dari daftar program studi yang ada di Universitas Muhammadiyah Surakarta. Kemudian pada baris 8 terdapat variable req untuk melakukan request ke server dari varibel url10 dengan method GET. Kode baris 10 sampai kode baris 16 digunakan untuk menghubungkan web scraper ke database.

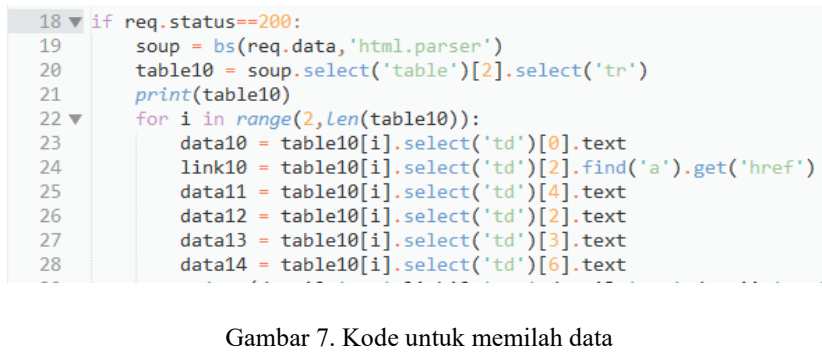

Gambar 7. Kode untuk memilah data

Potongan kode pada gambar 7 baris 18 menunjukkan kondisi pengecekan jika server memberi response. Variabel soup berfungsi untuk memisahkan dan mengubah data dari HTML menjadi kode yang lebih terstruktur. Kode baris 20 digunakan untuk memilah container data yaitu tabel ketiga dan mengambil semua baris pada tabel tersebut, kemudian kode baris 22 berfungsi sebagai looping untuk mengambil beberapa data yang diinginkan yang dipilah pada kode baris 23 sampai kode baris 28 dimulai dari baris tabel ke tiga sampai baris tabel terakhir. 


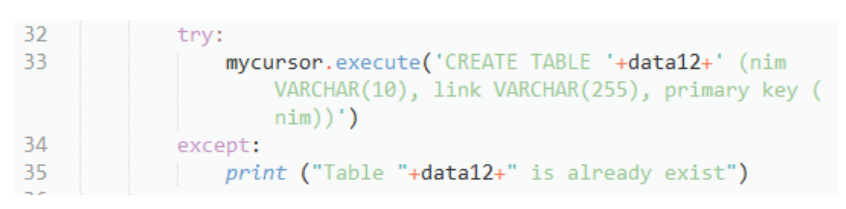

Gambar 8. Kode untuk memasukkan data dalam database

Data yang telah diambil pada baris 22 selanjutnya dimasukkan dalam sebuah database pada baris 33, data tersebut dimasukkan dalam bentuk tabel dengan nama tabel diambil dari variabel data12, sedangkan kode baris 35 merupakan exception kode baris 33 jika ada perulangan yang membuat data menjadi terduplikat.

Kemudian dari beberapa langkah diatas, dilakukan looping kembali dengan metode yang sama. Metode looping tersebut dilakukan dengan mengambil data berupa link dari data yang telah diambil sebelumnya sehingga program dapat menuju halaman berikutnya dan kembali mengambil data-data yang diperlukan. Maka didapatkan link profil mahasiswa seperti pada Gambar 9.

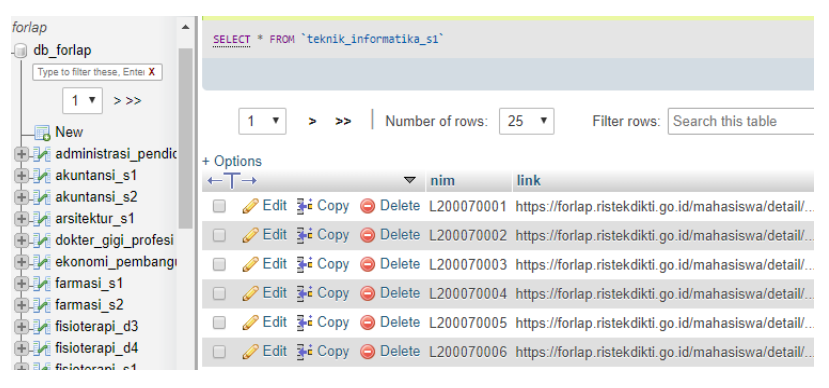

Gambar 9. Hasil proses web scraping

Link profil mahasiswa pada laman website Forlap Dikti mempunyai struktur yang sama pada setiap mahasiswa mulai dari protocol, domain, sub-domain, directories dan bagian dari URL yang terenkripsi, sehingga link tersebut bersifat konstan yang berarti link tidak akan berubah-ubah pada setiap pergantian semester maupun bahkan sejak mahasiswa mendaftar perguruan tinggi sampai terbit surat kelulusan dan ijazahnya. Maka data yang tersimpan dalam database aplikasi Forlap UMS tidak mempunyai masa kadaluwarsa, namun diperlukan update data pada setiap tahun ajaran baru untuk memasukkan data mahasiswa yang masuk pada tahun tersebut.

Dengan proses web scraping yang dilakukan, maka aplikasi Forlap UMS mempunyai database yang menyimpan seluruh link profil mahasiswa Universitas Muhammadiyah Surakarta pada laman Forlap Dikti dan memiliki sistem yang mampu melakukan redirect ke laman Forlap Dikti dengan lebih mudah.

Kemudian pada pemrograman aplikasi android, digunakan retrofit sebagai library untuk membantu komunikasi data antara android client dan REST API server. Retrofit bekerja dengan memberikan API endpoint pada base URL server. Hal tersebut dilakukan untuk menentukan API URL server yang akan diakses oleh android client untuk melakukan post request.

Retrofit akan membaca dan menangkap resource yang merupakan input berupa Nomor Induk Mahasiswa dan Program Studi untuk kemudian membuat koneksi dengan $A P I$ server menggunakan fungsi Retrofit.Builder(). Setelah API server memberi response, maka retrofit akan mengambil data dari database server dan mengkonversinya menjadi data yang dipresentasikan dalam bentuk JSON code. Saat android client telah menerima data berupa JSON code, data tersebut akan diterjemahkan menggunakan fungsi WebView yang tersedia pada Android Studio, maka apliksi Forlap UMS dapat mendefinisikan link yang terdapat pada JSON code kemudian mengalihkan halaman android client ke laman website Forlap Dikti sesuai dengan resource yang diberikan.

Aplikasi Forlap UMS diawali dengan halaman splash screen yang menampilkan sebuah logo dari Ristekdiki selama 1,5 detik yang langsung mengalihkan ke halaman home page. Halaman Home Page akan menampilkan tiga button antara lain button Forlap RistekDikti, button Pencarian Data dan button Tentang Aplikasi.

Button Forlap RistekDikti akan mengalihkan ke halaman yang memberikan informasi atau pengenalan tentang apa yang dimaksud dengan Forlap RistekDikti dan bagaimana pentingnya data mahasiswa untuk terdaftar didalamnya. Sedangkan button Pencarian Data akan menampilkan halaman form pencarian data, form tersebut terdiri dari field text input NIM dan combo box Program Studi yang ada di Universitas Muhammadiyah Surakarta. User yang telah melakukan input pada form tersebut akan diproses melalui hosting web server dan akan ditampilkan data mahasiswa dari input yang telah dimasukkan oleh user. Sedangkan pada button Tentang Aplikasi akan menampikan informasi tentang komponen yang digunakan untuk membangun aplikasi tersebut. Berikut merupakan tampilan aplikasi pada Gambar 10.

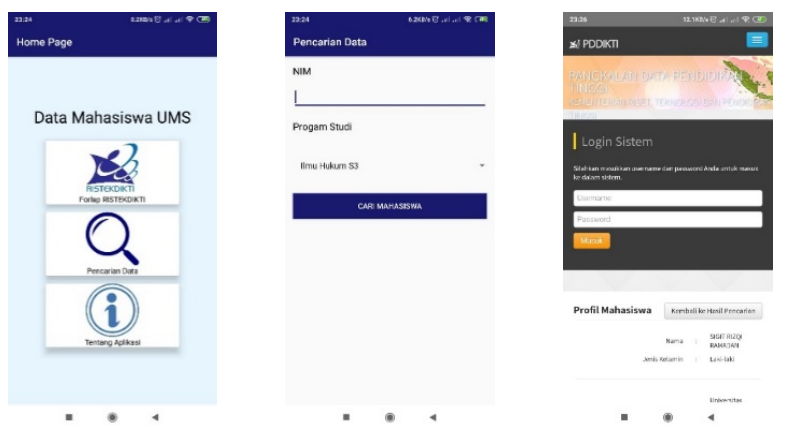

Gambar 10. Tampilan Aplikasi Forlap UMS 
Aplikasi yang telah dibangun selanjutnya akan melewati masa pengujian, tahap pengujian ini dilakukan dengan motede black box testing dan kuisioner. Pada metode pengujian black box testing, aplikasi diuji dengan memperhatikan spesifikasi, kondisi input maupun output, dan fungsionalitas dari sistem aplikasi tersebut. Berikut merupakan hasil pengujian dengan metode black box testing aplikasi Forlap UMS pada Tabel 1.

TABEL 1. HASIL PENGUJIAN BLACK BOX TESTING

\begin{tabular}{|l|l|l|l|}
\hline \multicolumn{1}{|c|}{ Button } & \multicolumn{1}{|c|}{ Test } & \multicolumn{1}{|c|}{ Hasil } & Kesimpulan \\
\hline Forlap \\
Ristekdikti & $\begin{array}{l}\text { Mengklik menu } \\
\text { Forlap Ristek } \\
\text { Dikti }\end{array}$ & $\begin{array}{l}\text { Menampilan } \\
\text { informasi tentang } \\
\text { Forlap Ristekdikti }\end{array}$ & Valid \\
\hline $\begin{array}{l}\text { Pencarian } \\
\text { Data }\end{array}$ & $\begin{array}{l}\text { Mengklik menu } \\
\text { Pencarian data }\end{array}$ & $\begin{array}{l}\text { Menampilkan form } \\
\text { pencarian data }\end{array}$ & Valid \\
\cline { 2 - 4 } & $\begin{array}{l}\text { Mengisi form } \\
\text { pencarian data }\end{array}$ & $\begin{array}{l}\text { Menampilkan hasil } \\
\text { input pencarian } \\
\text { data Valid }\end{array}$ & \\
\hline $\begin{array}{l}\text { Tentang } \\
\text { aplikasi }\end{array}$ & $\begin{array}{l}\text { Mengklik menu } \\
\text { Tentang Aplikasi }\end{array}$ & $\begin{array}{l}\text { Menampilkan } \\
\text { spesifikasi dan } \\
\text { materi pembangun } \\
\text { aplikasi }\end{array}$ & Valid \\
\hline
\end{tabular}

Proses pengujian selanjutnya yaitu pengujian dengan metode kuisioner kepada user yang merupakan mahasiswa Universitas Muhammadiyah Surakarta dari beberapa fakultas. Pengujian ini dilakukan dengan melakukan testing aplikasi secara langsung kepada user yang berjumlah 30 responden yang terdiri dari fakultas ilmu kesehatan (4 responden), fakultas teknik ( 2 responden), fakultas ekonomi dan bisnis (4 responden), fakultas farmasi (2 responden), fakultas komunikasi dan informatika (6 responden), fakultas hukukm (1 responden), dan fakultas keguruan dan ilmu pengetahuan (11 orang) kemudian user diminta untuk mengisi kuisioner yang berisi beberapa pertanyaan yang mempunyai relevansi dengan aplikasi yang dikembangkan. Berikut daftar pertanyaannya pada Tabel 2 .

TABEL 2. KODE DAN DAFTAR PERTANYAAN

\begin{tabular}{|l|l|}
\hline Kode & \multicolumn{1}{c|}{ Pertanyaan } \\
\hline P1 & Apakah aplikasi ini mudah digunakan? \\
\hline P2 & Apakah informasi pada aplikasi ini sudah lengkap? \\
\hline P3 & Apakah komposisi warna dan tampilan aplikasi ini menarik? \\
\hline P4 & Apakah tampilan aplikasi ini mudah dipahami? \\
\hline P5 & Apakah aplikasi ini efektif dalam pencarian data? \\
\hline P6 & $\begin{array}{l}\text { Apakah aplikasi ini memberi kemudahan dalam mencari dan } \\
\text { melihat data mahasiswa pada Forlap Dikti? }\end{array}$ \\
\hline
\end{tabular}

Perhitungan hasil dari kuisioner yang dilakukan adalah dengan cara menghitung prosentase dengan menjumlahkan skor dari setiap user kemudian dibagi dengan jumlah user yang sudah dikalikan dengan jumlah skor maksimal.

Kemudian dilakukan tahap pengujian dengan metode kuisioner, metode kuisioner dilakukan pengembang dengan cara mengumpulkan beberapa pertanyaan atau pernyataan yang memiliki relevansi maupun dengan aplikasi yang dikembangkan, kemudian diberikan kepada user yang merupakan mahasiswa umum Universitas Muhammadiyah Surakarta baik mahasiswa aktif maupun mahasiswa alumni. User diminta untuk mengisi memberi tanggapan dari pertanyaan atau pernyatan dengan menentukan tangkat persetujuan mereka dari setiap pertanyaan atau pernyataan menggunakan pertanyaan positif $(+)$ dengan memilih salah satu pilihan dengan ketentuan skor sebagai berikut:

TABEL 3. KETERANGAN SKOR

\begin{tabular}{|c|c|}
\hline Tanggapan & Nilai \\
\hline Sangat Setuju (SS) & 5 \\
\hline Setuju (S) & 4 \\
\hline Netral & 3 \\
\hline Tidak Setuju (TS) & 2 \\
\hline Sangat Tidak Setuju (STS) & 1 \\
\hline
\end{tabular}

Hasil dari kuisioner kemudian dihitung untuk mengetahui tingkat usability dari user dengan beberapa langkah perhitungan. Pertama pengembang menghitung jumlah skor yang didapat dari total jumlah user yang mengisi kuisioner dikalikan dengan pilihan angkar skor yang disediakan, rumus perthitungan jumlah skor adalah sebagai berikut:

\section{$\sum$ skor $=$ T x Pn}

Keterangan : $\quad \mathrm{T}=$ total jumlah user

$\sum$ skor $=$ jumlah skor $\quad \mathrm{Pn}=$ pilihan angka skor

Kemudian menghitung nilai interpretasi skor perhitungan dengan cara melakukan perkalian antara nilai skor tertinggi yang disediakan dengan jumlah user, maka diporoleh hasil perhitungan jumlah user sebanyak 30 orang dan nilai maksimal sebesar 5 poin, jadi skor maksimal yang didapat adalah 150. Sehingga didapatkan perhitungan penyelesaian akhir untuk menghitung indeks prosentase dari kuisioner responden dengan rumus sebagai berikut:

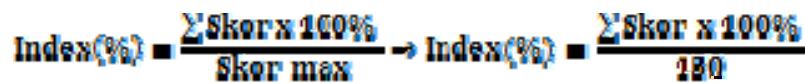

Hasil dari perhitungan kemudian ditampilkan dalam Tabel 4.

TABEL 4. HASIL PERHITUNGAN AKHIR KUESIONER

\begin{tabular}{|c|c|c|c|c|c|c|c|}
\hline \multirow{2}{*}{ Kode } & \multicolumn{5}{|c|}{ Tanggapan } & \multirow{2}{*}{ Jumlah } & \multirow{2}{*}{ Prosentase } \\
\hline & SS & $\mathbf{S}$ & $\mathbf{N}$ & TS & STS & & \\
\hline P1 & 25 & 4 & 1 & 0 & 0 & 144 & $96 \%$ \\
\hline $\mathrm{P} 2$ & 14 & 9 & 6 & 1 & 0 & 126 & $84 \%$ \\
\hline P3 & 10 & 15 & 5 & 0 & 0 & 125 & $83 \%$ \\
\hline $\mathrm{P} 4$ & 22 & 7 & 1 & 0 & 0 & 141 & $94 \%$ \\
\hline P5 & 20 & 6 & 4 & 0 & 0 & 136 & $91 \%$ \\
\hline P6 & 23 & 3 & 4 & 0 & 0 & 139 & $93 \%$ \\
\hline \multicolumn{7}{|c|}{ Total } & $90 \%$ \\
\hline
\end{tabular}




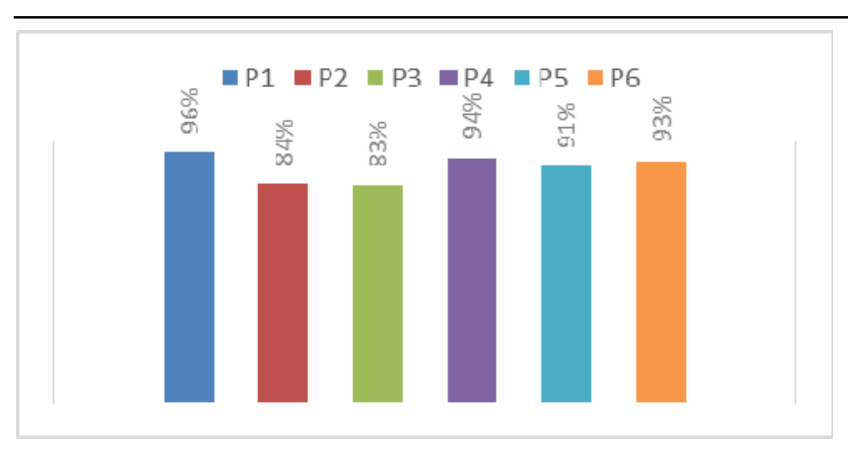

Gambar 11. Grafik Hasil Perhitungan Akhir Kuesioner

Berdasarkan pengisian kuisioner oleh user yang diwujudkan didalam tabel 4 dan gambar 11 maka didapatkan hasil sebagai berikut:

P1) 96\% menyatakan bahwa aplikasi mudah dioperasikan

P2) $84 \%$ menyatakan bahwa petunjuk dan informasi pada aplikasi sudah lengkap

P3) $83 \%$ menyatakan bahwa komposisi warna dan tampilan aplikasi menarik

P4) 94\% menyatakan bahwa tampilan aplikasi mudah dipahami

P5) $91 \%$ menyatakan bahwa aplikasi efektif dalam pencarian data

P6) 93\% menyatakan bahwa aplikasi memberi kemudahan dalam mencari dan melihat data mahasiswa pada Forlap Dikti.

Aplikasi ini mempunyai masih kekurangan yaitu beberapa link profil mahasiswa Univesitas Muhammadiyah Surakarta tidak ada dalam database hasil web scraping. Kekurangan tersebut mengakibatkan beberapa mahasiswa atau user yang menjadi responden dalam pengujian kuisioner tidak dapat menemukan datanya, hal itu dikarenakan adanya error pada file web scraping yang telah dirancang. Adapun cara mengatasinya adalah dengan memperbaiki lagi algortima dari script web scraper pada looping halaman daftar mahasiswa supaya semua data mahasiswa bisa diekstrak dan disimpan dalam database sehingga semua mahasiswa Univesitas Muhammadiyah Surakarta dapat menemukan data aktivitas akademik mereka di Forlap Dikti melalui aplikasi Forlap UMS.

\section{KESIMPULAN}

Aplikasi Forlap UMS telah dibangun dan diselesaikan oleh pengembang dengan merujuk pada konsep dan tujuan aplikasi. Hal tersebut dibuktikan dengan hasil dari pengujian blackbox testing dan pengujian kuisioner oleh user, berdasarkan analisa tersebut maka telah membuktikan bahwa aplikasi dapat berfungsi dengan baik dan menunjukan prosentase sebesar 90\% bahwa aplikasi Forlap UMS layak sebagai aplikasi alternatif untuk mengakses laman Forlap Dikti karena mampu memberi kemudahan kepada para mahasiswa Universitas Muhammadiyah Surakarta.

\section{DAFTAR PUSTAKA}

[1] L. Ma, L. Gu, and J. Wang, "Research and Development of Mobile Application for Android Platform,” vol. 9, no. 4, pp. 187-198, 2014.

[2] S. Mukherjee, P. J. Prakash, and D. Kumar, “Android Application Development \& Its Security,” vol. 4, no. 3, pp. 714-719, 2015.

[3] A. Josi et al., "PENERAPAN TEKNIK WEB SCRAPING PADA MESIN PENCARI ARTIKEL ILMIAH.”

[4] A. Ambre, P. Gaikwad, K. Pawar, and V. Patil, "Web and Android Application for Comparison of E-Commerce Products," no. 4, pp. 266-268, 2019.

[5] L. Richardson and S. Ruby, RESTful Web Services, First Edit. O'Reilly Media, Inc., 1005 Gravenstein Highway North, Sebastopol, CA 95472, 2007.

[6] Peraturan Menteri Pendidikan dan Kebudayaan Republik Indonesia "Ijazah, Sertifikat Kompetensi, dan Sertifikat Pendidikan Tinggi," Ber. Negara Republik Indones. Tahun 2014 Nomor 1179, pp. 1-12.

[7] H. Amrullah and B. Handaga, "SISTEM INFORMASI AKADEMIK UNTUK LAYANAN MAHASISWA UMS BERBASIS MOBILE,” J. Emit., vol. 17, no. 02, pp. 9-20, 2017. 